\title{
Recruitment of Thalassia testudinum seedlings into physically disturbed seagrass beds
}

\author{
Paula E. Whitfield ${ }^{1, *}$, W. Judson Kenworthy ${ }^{1}$, Michael J. Durako ${ }^{2}$, \\ Kamille K. Hammerstrom ${ }^{1}$, Manuel F. Merello ${ }^{3}$ \\ ${ }^{1}$ NOAA Beaufort Laboratory, 101 Pivers Island Road, Beaufort, North Carolina 28516, USA \\ ${ }^{2}$ University of North Carolina-Wilmington, Center for Marine Science, 5600 Marvin Moss Road, Wilmington, \\ North Carolina 28409, USA
}

${ }^{3}$ Fish and Wildlife Conservation, Florida Marine Research Institute, 100 Eighth Ave. S.E., St. Petersburg, Florida 33701, USA

\begin{abstract}
Thalassia testudinum seedling recruitment, survival, and growth were examined within physically disturbed seagrass beds in the Florida Keys. Two separate studies were conducted. In the first, a large-scale study, $T$. testudinum seedlings were surveyed and collected from a large seagrass disturbance $\left(1560 \mathrm{~m}^{2}\right), 4.8 \mathrm{yr}$ after the initial impact from a motor-vessel grounding. In the second, a smaller-scale study, $T$. testudinum seedling recruitment was examined over a $2 \mathrm{yr}$ period within 9 smaller motor-vessel disturbances located within intact $T$. testudinum beds. In the large-scale study, we reconstructed the age of the seedlings based on shoot production rates from a previous study and from the small-scale study. A total of 79 seedlings were collected that varied in age from young of the year to $4.8 \mathrm{yr}$ old; 6 different seedling cohorts were identified. The average density and rhizomeelongation rate for $1 \mathrm{yr}$ old seedlings were $1 \mathrm{~m}^{-2}$ and $6.6 \mathrm{~cm} \mathrm{yr}^{-1}$, respectively. In the small-scale study, we surveyed and permanently marked all newly recruited seedlings; monitoring was conducted 5 more times over a 2 yr period. The average seedling survival after Year 1 was $42 \%$; after Year 2, average survival dropped to $20 \%$. The average seedling density after Year 1 was $0.071 \mathrm{~m}^{-2}$; after Year 2, average density dropped to $0.026 \mathrm{~m}^{-2}$. The average rhizome-elongation rate and shootproduction rate of $1 \mathrm{yr}$ old seedlings were $6 \mathrm{~cm} \mathrm{yr}^{-1}$ and 1.8 shoots $\mathrm{yr}^{-1}$, respectively. The results of this study suggest that $T$. testudinum seedlings are a regular and reliable source of new recruits on seagrass banks in the Florida Keys.
\end{abstract}

KEY WORDS: Thalassia testudinum $\cdot$ Seedling $\cdot$ Disturbance $\cdot$ Succession $\cdot$ Seagrass $\cdot$ Recovery process $\cdot$ Sexual reproduction

Resale or republication not permitted without written consent of the publisher

\section{INTRODUCTION}

Worldwide, seagrasses are crucial to the structure and function of healthy coastal ecosystems (Hemminga \& Duarte 2000). In the western Atlantic, Caribbean, and Gulf of Mexico, Thalassia testudinum (turtle grass) is one of the most abundant seagrass species (Zieman 1982, Zieman \& Zieman 1989, Fourqurean et al. 2001). Intact $T$. testudinum beds can be long-lived (Zieman 1982) and extremely resilient to severe storms (Thomas et al. 1961, Oppenheimer 1963, Williams 1990, Tilmant et al. 1994). Of the 7 seagrass species indigenous to the sub-tropical western Atlantic, T. testudinum has the largest and most complex root and rhizome system, the widest strap-like blades, and an upward branching growth strategy that allows it to build extensive, stable, elevated bank systems (Ginsburg \& Lowenstam 1958, Tomlinson \& Vargo 1966, Zieman 1972,1982). However, compared to other seagrasses, $T$. testudinum has one of the slowest rhizome-elongation rates and is therefore slow to recover from disturbance events (Patriquin 1973, Tomlinson 1974, Zieman 1982, Williams 1990, Duarte 1991, Kenworthy et al. 2002).

In shallow-water areas of southern Florida, USA, seagrasses are being lost at an alarming rate due to motor-vessel disturbances (Sargent et al. 1995). These 
impacts range from relatively shallow, linear features called 'prop scars' (Zieman 1976, Durako et al. 1992, Folit \& Morris 1992, Dawes et al. 1997, Kenworthy et al. 2002) to larger and deeper 'blowhole' injuries (Whitfield et al. 2002). Propeller scars can be long-lasting features with recovery times ranging from 2 to 26 yr and averaging 5 to $10 \mathrm{yr}$ in T. testudinum meadows (Zieman 1976, Durako et al. 1992, Dawes et al. 1997, Kenworthy et al. 2002). Blowholes are polygonalshaped features that can be several meters deep, with physically unstable edges (Whitfield et al. 2002). For larger blowhole features, there have been no documented cases of complete recovery, possibly due to the physical instability and the steep topographic gradient associated with the perimeter of these features (Whitfield et al. 2002).

Recovery dynamics within disturbed tropical and sub-tropical North American seagrass communities have been documented in several studies (den Hartog 1971, Patriquin 1975, Zieman 1982, Williams 1987,1990, Fourqurean et al. 1995, Kenworthy et al. 2002, Whitfield et al. 2002), leading to a paradigm that describes a deterministic sequence of colonization and recovery. The substrate is first occupied by calcareous and rhizophytic macroalgae that may facilitate seagrass colonization through sediment stabilization, enhanced sedimentation, and by increasing nutrients in pore water (den Hartog 1971, Patriquin 1975, Zieman 1982, Williams 1990). Next, depending on the local species composition, the faster growing sea- grasses Halodule wrightii (shoal grass) and/or Syringodium filiforme (manatee grass) continue the process of recovery through vegetative growth from adjacent populations. In the final stages of the recovery process, the climax species Thalassia testudinum begins to colonize by rhizome growth from adjacent populations and, under optimum conditions, eventually displaces the other seagrass species (Williams 1987, 1990). The degree of displacement is dependent upon environmental factors such as sediment depth, nutrient availability, and the disturbance regime.

This paradigm discounts the role of Thalassia testudinum seedlings in the recovery process. This is probably due to the general lack of understanding of the role of sexual reproduction and seedling recruitment in seagrass systems (Inglis 2000, Kenworthy 2000, Orth et al. 2000). Seedlings have been considered unimportant to seagrass recovery and bed maintenance in most, relatively large perennial species like T. testudinum (Campey et al. 2002). With the exception of 1 study of $T$. testudinum seedling recruitment in Laguna Madre, Texas (Kaldy \& Dunton 1999), there has been little direct empirical research examining the contribution of $T$. testudinum seedlings in seagrass meadow dynamics. More recently an increasing body of evidence, mainly elucidated through genetic studies, has suggested a larger role for $T$. testudinum seedlings than previously thought (Kirsten et al. 1998, Davis et al. 1999, Waycott \& Barnes 2001).
Fig. 1. Thalassia testudinum. (A) Fruit found floating on water surface. (B) Same fruit cut in half to reveal $1 T$. testudinum seedling with primordial leaf already developed within the fruit. (C) New seedling recruit not yet established, with no visible roots or sediment particles attached. (D) New seedling recruit showing evidence of previous sediment establishment, with sediment particles adhered to root hairs on seed
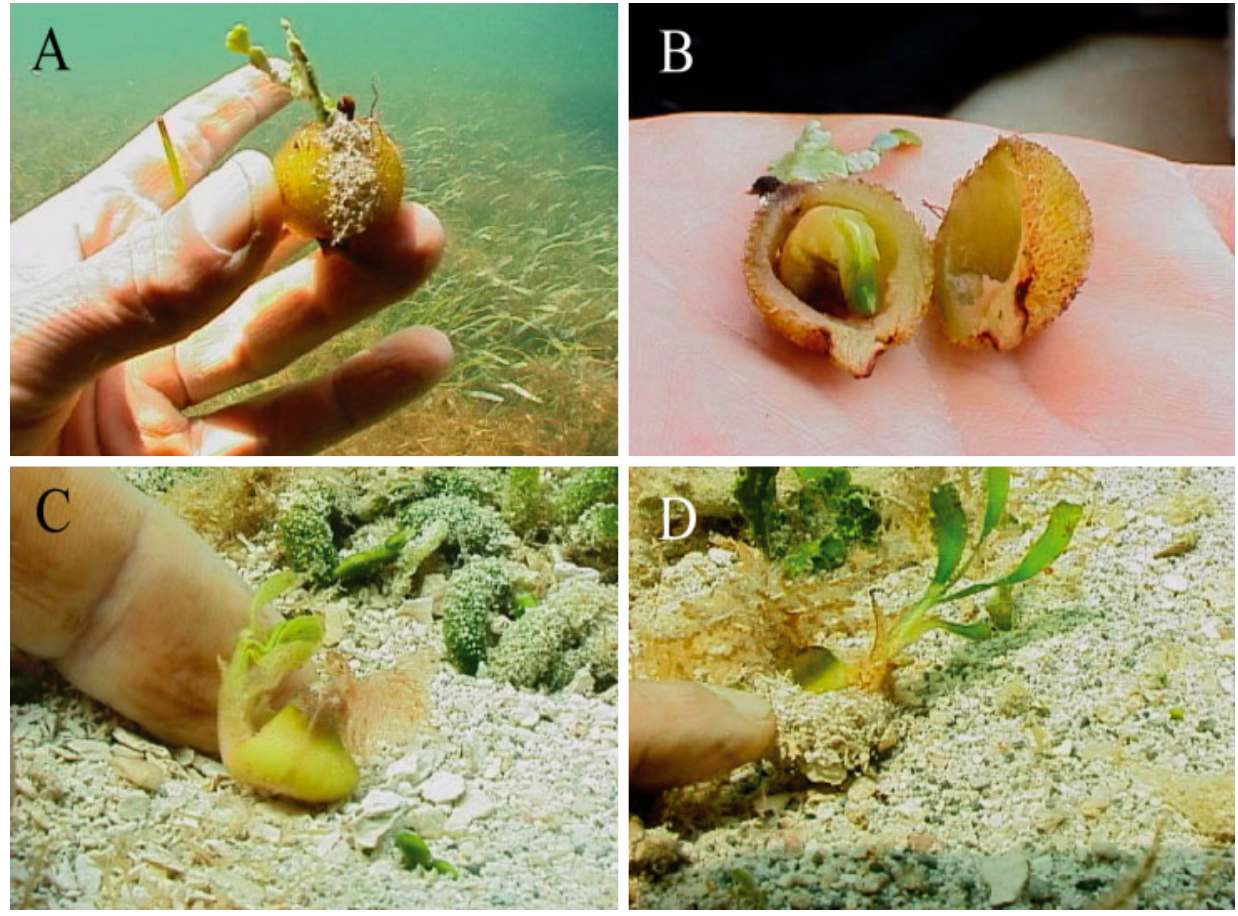
In South Florida, Thalassia testudinum flowers from April to July, with peak inflorescence densities in June (Tomlinson 1969). As is the case for other seagrasses, reproductive effort can be prolific, but is variable on an inter-annual time scale (Orpurt \& Boral 1964, Lewis \& Phillips 1980, Williams \& Adey 1983, Durako \& Moffler 1985,1987, Campey et al. 2002). Fruits mature from July to September, producing from 1 to 3 seedlings fruit $^{-1}$ (Orpurt \& Boral 1964, Tomlinson 1969). Germination of the seed and appearance of primordial leaves occur within the fruit before the fruit dehisces (Fig. 1) (Orpurt \& Boral 1964, Tomlinson 1969), so there is no lag time in germination and, therefore, no $T$. testudinum seed bank. Among the 7 North American seagrass species, T. testudinum seedlings are the largest and most robust, containing enough carbohydrate reserve to support the seedling for at least 6 mo (Kaldy \& Dunton 1999). Peak T. testudinum seedling recruitment in the Florida Keys is generally believed to occur in September; however, the fruits and seedlings are buoyant, so long-distance dispersal is possible for extended periods of time.

The primary objective of the present study was to describe and quantify the recruitment, survival, and growth of Thalassia testudinum seedlings at several disturbance sites where $100 \%$ of the seagrasses had been removed. $T$. testudinum seedling recruitment processes are also discussed in this paper, within the context of the current seagrass community recovery

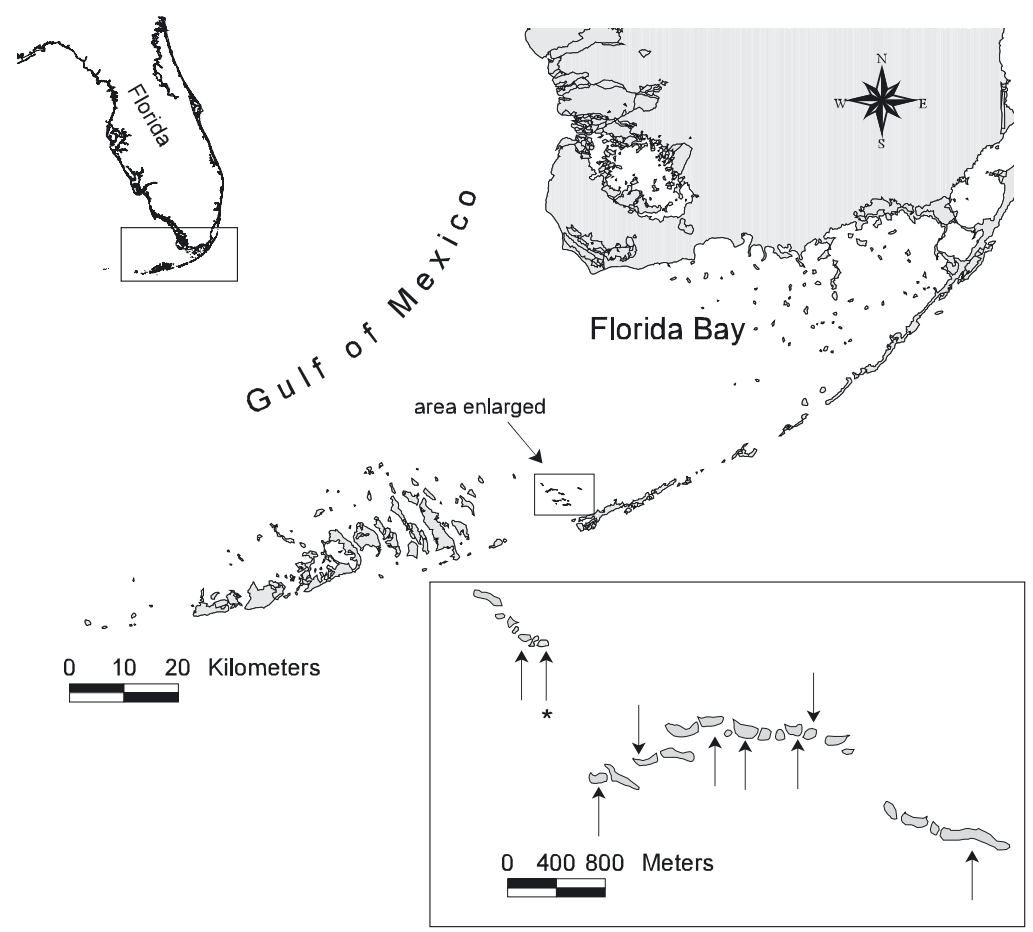

Fig. 2. Map of the study sites in the Florida Keys. *: large-scale study location; remaining arrows: injury locations from the small-scale study paradigm described in the literature. To our knowledge, our seedling data are the first long-term data sets ( $>2 \mathrm{yr}$ ) of $T$. testudinum seedling recruitment and survival.

\section{MATERIALS AND METHODS}

Study site. The study site is located in the middle region of the Florida Keys on a series of elevated seagrass-Porites coral banks known as Red Bay Banks (Fig. 2). The banks form part of a nearly continuous live bottom community that extends north into Florida Bay and southwest into the Gulf of Mexico, interspersed with large seagrass meadows dominated by a mixture of Thalassia testudinum and Syringodium filiforme (Kenworthy \& Schwarzschild 1998, Rose et al. 1999, Fourqurean et al. 2001). The bank substrate is composed mainly of dead Porites finger coral mixed with other biogenic calcium carbonate fragments and finer sediments. Tides are semi-diurnal, with maximum currents on the order of 1.5 to 2.0 knots. Strong tidal currents in combination with wind waves produce an energetic hydrodynamic regime.

Two separate experiments were conducted. In the first study (large-scale), Thalassia testudinum seedlings were quantified at a large $\left(1560 \mathrm{~m}^{2}\right)$ disturbance site, after $4.8 \mathrm{yr}$ of recovery. In the second study (smallscale), T. testudinum seedling recruitment, survival, and growth were surveyed over a 2 yr period in 9 smaller disturbance areas grouped into 3 size classes averaging 56, 171 , and $326 \mathrm{~m}^{2}$. From these data sets we were able to obtain information on $T$. testudinum seedling recruitment, survival, and growth up to the first $4.8 \mathrm{yr}$ of life.

Large-scale study $\left(>\mathbf{1 0 0 0} \mathbf{~ m}^{\mathbf{2}}\right)$. In May 1993, a large disturbance $\left(7200 \mathrm{~m}^{2}\right)$ was created near the western end of Red Bay Bank by a $15.4 \mathrm{~m}$ tugboat with a 3-m draft, which ran aground on a shallow seagrass bank (Fig. 3). This disturbance removed $100 \%$ of the above-ground banktop community and below-ground seagrass rhizome matrix, creating a 2 to $3 \mathrm{~m}$ trench and depositing sediments into shallower berms on either side (see Whitfield et al. 2002). Over the next $4.8 \mathrm{yr}$, recovery of the site was limited to recolonization by the primary colonizer, Syringodium filiforme, from the perimeter of the injury, with only macroalgae and Thalassia testudinum seedling recruitment occurring in the most severely disturbed area (Fig. 3). In January 1998 , we mapped the perimeter of the 


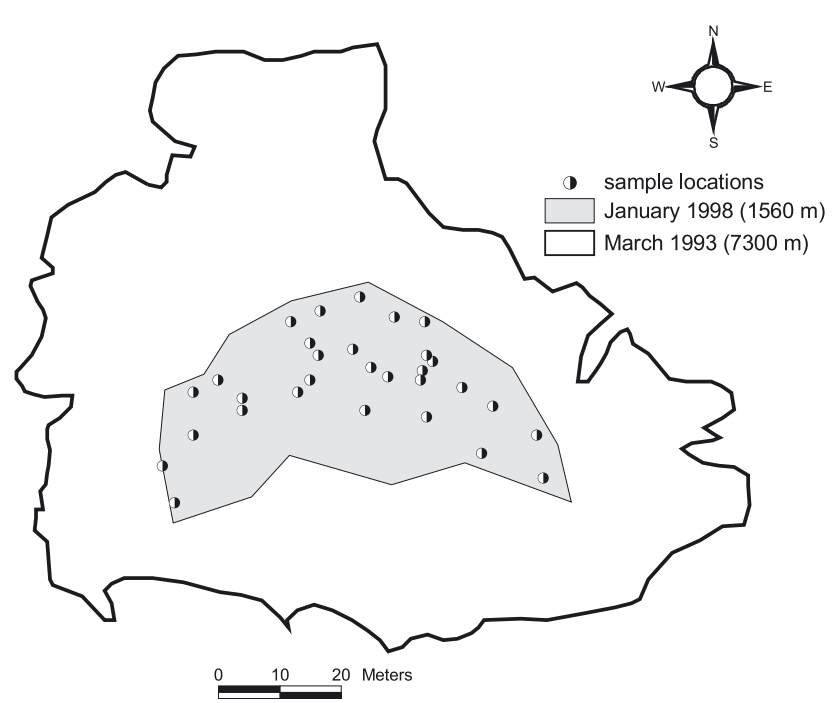

Fig. 3. Two perimeters mapped from the large-scale study shortly after the boat grounding occurred in May 1993 (area $\sim 7300 \mathrm{~m}^{2}$ ) and $4.8 \mathrm{yr}$ later, when the site was sampled for presence of Thalassia testudinum seedlings in January 1998 (area $\sim 1560 \mathrm{~m}^{2}$ ). White area indicates recovery by Syringodium filiforme and gray area represents the remaining unrecovered area. Sample locations are indicated inside the January 1998 perimeter

unrecovered area remaining at the site using a differential GPS unit (Trimble GPS Pathfinder, Pro XR/XRS Receiver). Next, divers collected all of the seedlings found within 35 randomly placed $1 \mathrm{~m}^{2}$ quadrats in the remaining $1560 \mathrm{~m}^{2}$ disturbance area (Fig. 3). Care was taken to excavate each seedling completely intact without breaking any of the above- or below-ground structure. Each excavated seedling contained a visible seed and was positively identified as a seedling. Because the seedlings were no older than $4.8 \mathrm{yr}$, a relationship between shoot number and seedling age could be developed. Age classes were assigned based on the number of vertical short-shoots per seedling, using the seedling shoot-formation rate reported by Kaldy \& Dunton (1999) and the 1 yr old seedlings collected in our small-scale study (described in the following subsection). Seedlings with 1 shoot were considered the Year 0 age class, or new recruits. Seedlings with 2 to 3 shoots were classified as 1 yr old seedlings. Those with 4 to 6 shoots were considered to be 2 yr old seedlings, while those with 7 or 8 shoots were considered 3 yr old seedlings. There were only 2 seedlings with $>8$ shoots. One had 13 shoots and was placed in the 3 yr age class, while the largest seedling had 22 shoots and was placed in the 4 yr age class. However, due to the variability in shoot-production rates among seedlings found in the small-scale study (1 to 4 shoots produced in Year 1), it is possible that there is some overlap among the consecutive age categories. However, no seedling could have been older than $4.8 \mathrm{yr}$.
Seedling density was calculated for the Year 1 age class only. Rhizome-elongation rate and horizontal rhizome-branching rate for the Year 1 and Year 2 age classes were also calculated.

Small-scale study $\left(<\mathbf{4 0 0} \mathbf{~ m}^{\mathbf{2}}\right)$. Nine disturbance features on Red Bay Banks, also caused by motor-vessel groundings, were chosen to represent a range of sizes that were commonly observed in this area (Fig. 4). The 9 features, hereafter referred to as injuries, were grouped into 3 size categories, small (SM) $<100 \mathrm{~m}^{2}$, medium (MED) 132 to $200 \mathrm{~m}^{2}$, and large (LG) $>300 \mathrm{~m}^{2}$ (Fig. 4).

Prior to initiating seedling recruitment surveys, all of the existing seedlings were removed from the 9 injuries in June 2000. Beginning in September 2000, all new seedling recruits of a known age $(<3$ mo old) in each injury were visually surveyed by divers. The seedlings were located, counted, and marked by inserting a metal reinforcement bar (rebar) into the sediment adjacent to each seedling. Seedling abundance and survival in the 9 injuries were surveyed 5 additional times over the course of a 2 yr period: January 2001, May 2001, September 2001, May 2002, and August 2002. Any additional seedling recruits found between September 2000 and May 2001 were subsequently marked with rebar and considered new recruits.

During the September 2001 observation period, the $1 \mathrm{yr}$ old survivors were surveyed, and new recruits (young of the year) were identified and counted. The additional survey of new recruits was conducted to assess the inter-annual variability of seedling recruitment during the same time period (September) of 2 consecutive years.

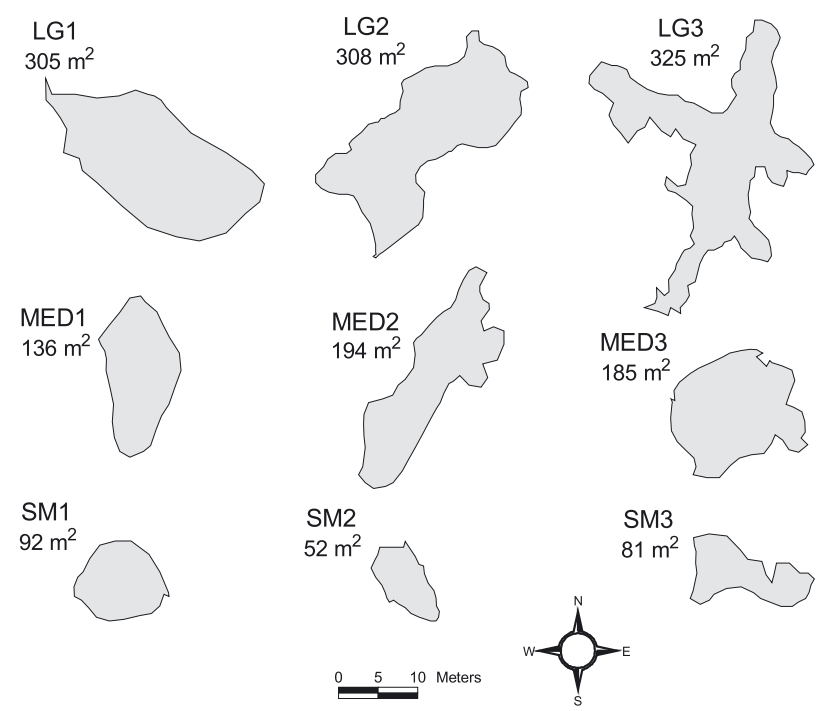

Fig. 4. Nine injury perimeter maps, of 3 size categories, from the small-scale study in June 2000 located on Red Bay Bank. LG: large; MED: medium; SM: small 
Seedling density and abundance was computed for each injury and survey period. Seedling survival was calculated for each injury at the end of Year 1 and Year 2, in September 2001 and August 2002, respectively. Since seedling abundance increased over time for some injuries, the percent survival at Year 1 and Year 2 for each injury was calculated by dividing the final seedling abundance in September 2001 and August 2002 by the highest seedling abundance that occurred during the previous sample periods. Because the data could not be transformed to meet the assumptions of parametric statistics, we used a nonparametric 2 -factor analysis of variance to test for statistical differences among the seedling densities by injury size and survey period (Zar 1984). Any significant main effects were examined further with nonparametric multiple comparisons. We chose 3 of the 6 survey periods for this analysis, to test for differences in density at Year 0, Year 1, and Year 2 (September 2000, September 2001, and August 2002).

Seedling growth was determined from measurements of rhizome length, total short shoots, and branch number from 30 randomly selected $1 \mathrm{yr}$ old seedlings collected from 6 of the 9 injuries in September 2001. The small injuries did not have enough seedlings to sample. Although we did not collect any 2 yr old seedlings, we did record the number of shortshoots in situ. Measurements for the oldest shoot on each seedling (Shoot 1, Fig. 5) were also collected and include: leaf length and width, total leaves produced

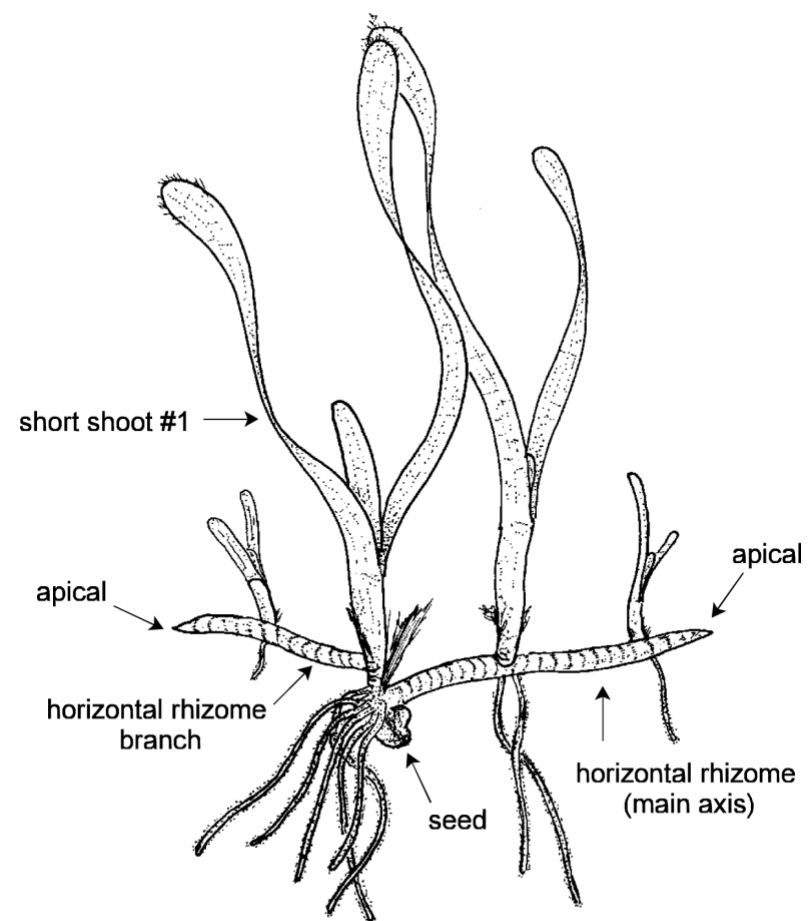

Fig. 5. Thalassia testudinum. Line drawing of a seedling, depicting the horizontal rhizome, apical horizontal rhizome branch, short-shoot, seed. Courtesy of M. S. Fonseca (leaf scars + leaves present) on the shoot, and the leaf number (only leaves present). Evidence of herbivory (bite marks) was also noted for each seedling.

\section{RESULTS}

\section{Large-scale study}

Because this disturbance removed $100 \%$ of the seagrasses from the bank top, all of the seedlings in this data set were known to be $<4.8$ yr of age. This provided a unique opportunity to examine the demographics of a young seedling population. Four different seedling cohorts were identified in this population, representing a data set for the longest known sampling period of Thalassia testudinum seedlings $(4.8 \mathrm{yr})$ (Fig. 6). A total of 79 seedlings were collected. The number of short-shoots per seedling ranged from 1 to 22 , and $81 \%$ of the seedlings had 3 shoots or less. The majority of the seedlings in this population were $<2 \mathrm{yr}$ of age (Fig. 6). The seedling density for the Year 1 cohort was $1 \mathrm{~m}^{-2}$. Within the Year 1 age class, the average rhizome-elongation rate was $6.6 \mathrm{~cm} \mathrm{yr}^{-1}$ and the branching frequency was $22 \%$. Within the Year 2 age class, the average rhizome-elongation rate was $8.5 \mathrm{~cm}$ $\mathrm{yr}^{-1} ; 83 \%$ of these seedlings produced 1 branch and $17 \%$ of those produced 2 branches (Table 1). The longest rhizome recorded from the population was $65 \mathrm{~cm}$. For this particular seedling the rhizomeelongation rate averaged $13.5 \mathrm{~cm} \mathrm{yr}^{-1}$.

\section{Small-scale study}

Most of the seedling recruitment occurred in the medium and large injuries (Figs. 7 \& 8). Average survival after $2 \mathrm{yr}$ in the small injuries was $25 \%$, but only 1 seedling survived (Fig. 7). This result is primarily due to the SM1 injury, which had 2 seedlings recruit and 1 survive, thereby skewing the survival estimates within the small injuries. Also, no seedlings recruited into the SM3 injury; therefore, survival could not be calculated (Table 2). After Year 1 and Year 2 the average density in the small injuries was 0.003 seedlings $\mathrm{m}^{-2}$ (Table 2).

Seedling recruitment in the medium injuries continued to increase from the September 2000 to the May 2001 survey (Fig. 7). After 1 yr, in September 2001, average seedling abundance was still higher than during the first survey (Fig. 7). The average seedling survival for the medium injuries decreased from $54 \%$ in September 2001 to $21 \%$ in August 2002 (Table 2). Similarly, seedling density also decreased from 0.16 to 0.06 seedlings $\mathrm{m}^{-2}$ from Year 1 to Year 2 in the medium injuries (Fig. 8). 

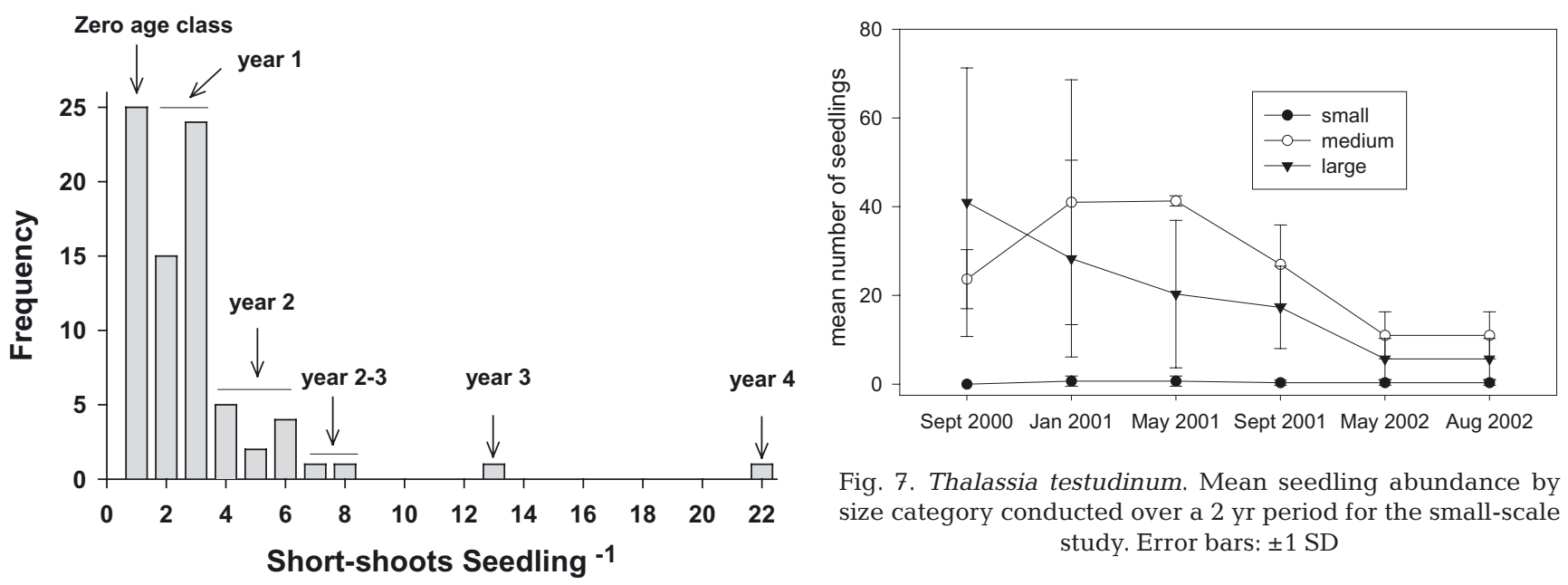

Fig. 7. Thalassia testudinum. Mean seedling abundance by size category conducted over a 2 yr period for the small-scale study. Error bars: $\pm 1 \mathrm{SD}$

Fig. 6. Thalassia testudinum. Frequency distribution of seedling age cohorts from the large-scale study. Age classes based on total shoot number and age relationships derived from the small-scale study and Kaldy \& Dunton (1999)

In contrast to the medium injuries, seedling abundance in the large injuries decreased during each consecutive survey (Fig. 7). Seedling density in the large injuries was also lower than in the medium injuries. Average seedling density in the large injuries decreased from $0.05 \mathrm{~m}^{-2}$ in September 2001 to $0.015 \mathrm{~m}^{-2}$ in August 2002 (Fig. 8). Seedling survival in the large injuries decreased from $48 \%$ to $14 \%$ between Year 1 and Year 2 (Table 2). After $1 \mathrm{yr}$, seedling survival averaged $50 \%$ in the medium and large size categories. Over the following winter the $1 \mathrm{yr}$ old seedlings experienced $65 \%$ mortality, decreasing their survival in May 2002 to $17.6 \%$. Seedling survival remained the same 3 mo later in August 2002. During the final survey the percent sur-

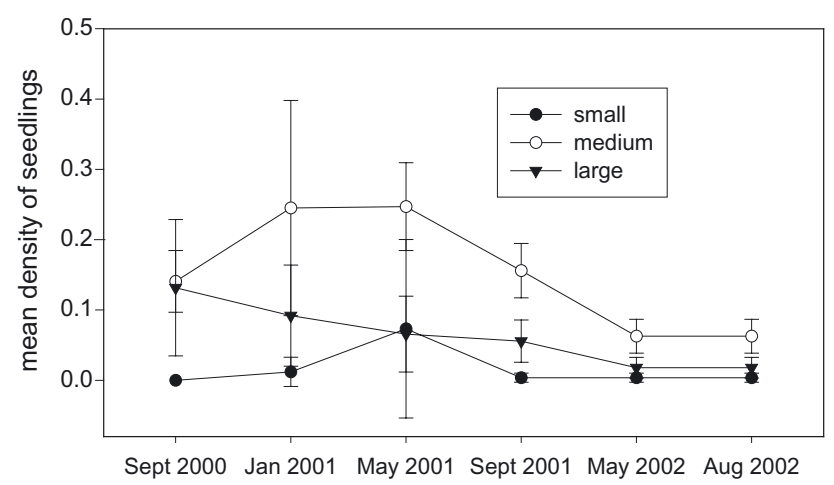

Fig. 8. Thalassia testudinum. Mean seedling density by size category conducted over a $2 \mathrm{yr}$ period for the small-scale study. Error bars: \pm 1 SD. Mean seedling densities for each size category for the 2 -yr period were medium $=0.12 \mathrm{~m}^{-2}$, large $=0.068 \mathrm{~m}^{-2}$, small $=0.002 \mathrm{~m}^{-2}$

vival for the medium and large injuries ranged from $10 \%$ to $24 \%$ (Table 2). A comparison of the new recruits surveyed in September 2000 with the new young-of-year recruits in

Table 1. Thalassia testudium. Morphometrics data collected from Year 1 and Year 2 seedlings in the large- and small-scale studies compared to 15 mo old seedlings in Kaldy \& Dunton (1999). -: data not collected September 2001 suggests that there was considerable variability in the inter-annual recruitment patterns among the different size categories (Fig. 9).

Results of the nonparametric 2-factor analysis of variance indicate that significant differences among seedling densi-

\section{Large-scale study}

(1 yr old seedlings, $n=39$ )

(2 yr old seedlings, $\mathrm{n}=12$ )

Small-scale study

( 1 yr old seedlings, $\mathrm{n}=30$ )

( 2 yr old seedlings, $\mathrm{n}=54$ )

Kaldy \& Dunton (1999)

15 mo old seedlings

$\begin{array}{ccc}\begin{array}{c}\text { Rhizome } \\ \text { elongation rate } \\ \left(\mathrm{cm} \mathrm{yr}^{-1}\right)\end{array} & \begin{array}{c}\text { Mean number } \\ \text { of shoots } \\ \text { per seedling }\end{array} & \begin{array}{c}\text { Branching rate } \\ (\%)\end{array}\end{array}$

$\begin{array}{ccc}6.6 & - & 22(1 \text { branch }) \\ 8.5 & - & 83(1 \text { branch }) \\ & & 17(2 \text { branches })\end{array}$$$
6
$$$$
-
$$

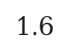

2.4

26 (1 branch)

$-\quad 2.4$

10

$3-5$ ties existed by injury size only ( $H_{\text {stat }}=$ $\left.18.32, \chi_{(0.05,2)}^{2}=5.991, \mathrm{p}<0.001\right)$. Further, the results of the nonparametric multiple comparison test indicate that the mean seedling density within the small size category was significantly different from the other size categories, and there was no significant difference 
Table 2. Thalassia testudium. Density and survival for Year 1 and Year 2 seedlings from all 9 injuries in the small-scale study. SM: small; MED: medium; LG: large

\begin{tabular}{|c|c|c|c|c|c|}
\hline & \multirow{2}{*}{ Area $\left(\mathrm{m}^{2}\right)$} & \multicolumn{2}{|c|}{ Survival } & \multicolumn{2}{|c|}{ Density } \\
\hline & & Year 1 & Year 2 & Year 1 & Year 2 \\
\hline SM 1 & 92 & $50 \%$ & $50 \%$ & 0.01 & 0.01 \\
\hline SM 2 & 56 & 0 & 0 & 0 & 0 \\
\hline SM 3 & 81 & $--^{a}$ & $--^{a}$ & 0 & 0 \\
\hline SM mean & & $25 \%{ }^{b}$ & $25 \%{ }^{b}$ & 0.003 & 0.003 \\
\hline MED 1 & 132 & $48 \%$ & $17 \%$ & 0.15 & 0.05 \\
\hline MED 2 & 200 & $53 \%$ & $24 \%$ & 0.19 & 0.08 \\
\hline MED 3 & 188 & $60 \%$ & $22 \%$ & 0.13 & 0.05 \\
\hline MED mean & & $54 \%$ & $21 \%$ & 0.16 & 0.06 \\
\hline LG 1 & 302 & $42 \%$ & $10 \%$ & 0.04 & 0.001 \\
\hline LG 2 & 310 & $37 \%$ & $15 \%$ & 0.09 & 0.035 \\
\hline LG 3 & 325 & $65 \%$ & $18 \%$ & 0.03 & 0.009 \\
\hline LG mean & & $48 \%$ & $14 \%$ & 0.05 & 0.015 \\
\hline
\end{tabular}
and only 2 dead shoots were found. Short-shoot measurements obtained from Shoot 1 (oldest shoot) of the 30 seedlings indicated that the average leaf length and width were 10.4 and $0.78 \mathrm{~cm}$, respectively (Table 3$)$. The total number of leaves produced during the shoot's life span (leaf scars + standing leaves) averaged 12.9, with an average of 3.1 leaves short-shoot ${ }^{-1}$ (Table 3 ). The average shoot-formation rate after Year 2 was 2.4 shoots seedling ${ }^{-1}$ (Table 1). All 30 seedlings showed some evidence of leaf grazing.

\section{DISCUSSION}

Evidence collected from 2 separate spatial scales suggests that Thalassia testudinum seedlings were able to recruit, survive, and grow in a severely disturbed environment, where sediments were excavated and currents exceeded 1 knot. Our data and observations since 1993 also suggest that annual T. testudinum seedling recruitment events have occurred in this

Table 3. Thalassia testudium. Vertical short-shoot measurements for Year 1 seedlings $(n=30)$ in the small-scale study. All 30 short-shoot measurements were from the oldest shoot of each seedling

\begin{tabular}{|lcc|}
\hline & Mean & SE \\
\hline Leaf length $(\mathrm{cm})$ & 10.4 & 6.1 \\
Leaf width $(\mathrm{cm})$ & 0.78 & 0.16 \\
Total leaves produced & & \\
(leaves + leaf scars) & 12.9 & 3.4 \\
Number of leaves present & 3.1 & 0.8 \\
\hline
\end{tabular}


environment for at least 10 yr. Surprisingly, we found evidence that there was a period of seedling redistribution and recruitment that extended at least 8 mo beyond the peak recruitment period previously thought to be in September of each year. This extended period of seedling recruitment has never before been quantitatively verified, although other researchers have speculated about this phenomenon (Michael J. Durako pers. obs., Manuel F. Merello pers. obs.). Together, these findings suggest that $T$. testudinum seedlings may be more important in the seagrass recovery process than previously thought.

\section{Thalassia testudinum seedling recruitment: density, survival, and growth}

This is the second field study to quantify Thalassia testudinum seedling recruitment, survival, and growth under natural conditions. Kaldy \& Dunton (1999) examined seedling recruitment and survival in unvegetated disturbance areas created within monotypic $T$. testudinum meadows, presumably by the overgrowth and shading of macroalgae that killed $T$. testudinum in Laguna Madre, Texas. Density of 1 yr old seedlings found in the disturbance areas in Laguna Madre averaged 1 seedling $\mathrm{m}^{-2}$ (Kaldy \& Dunton 1999). This is the same as the density of 1 -yr-old seedlings estimated in our large-scale study $\left(1 \mathrm{~m}^{-2}\right)$. However, both the largescale and Kaldy \& Dunton's (1999) studies had higher seedling densities than we observed among the 9 injuries in the small-scale study at Year $1\left(0.07 \mathrm{~m}^{-2}\right)$ and Year $2\left(0.026 \mathrm{~m}^{-2}\right)$. This approximates to 1 seedling every $14 \mathrm{~m}^{2}$ and every $38 \mathrm{~m}^{2}$ after Years 1 and 2, respectively. However, the seedling densities in the medium and large injuries after Year $1\left(0.16 \mathrm{~m}^{-2}\right.$ and $0.05 \mathrm{~m}^{-2}$, respectively) were comparable to the density of $1 \mathrm{yr}$ old seedlings surveyed at a disturbance site on the ocean side of the Florida Keys near Craig Key $\left(0.08 \mathrm{~m}^{-2}\right)$ (Lewis \& Phillips 1980). In the small-scale study, no density differences were detectable by date, even though seedling mortality was demonstrated during the 2 yr study period. The lack of any date effect on seedling density may be attributed to the amount of variability among the injury sizes. However, the mean seedling density in the small injuries was significantly different than that in both the medium and the large sizes. The lowest seedling densities were found in the small injuries, and the highest, in the medium injuries (Fig. 8). While interesting, because the small injuries showed little recruitment in general and the medium injury size contained the highest densities, it is difficult to interpret the meaning of this result. However, these data may point to a variety of environmental factors other than injury size that may influence seedling recruitment, such as the presence of macroalgae and sediment stability. This merits further investigation.

Among seagrasses there appear to be considerable variation in seedling abundance and levels of seedling importance that are related to different life-history strategies. Seedlings appear to be less abundant in longer-lived climax species than in shorter-lived opportunistic species, such as Halophila decipiens and Zostera marina, which have a seed bank. For these opportunistic species seedlings are often the most important life stage for seasonal re-growth and recovery from disturbance (Kenworthy 2000). Seedling densities as high as 10 to $27 \mathrm{~m}^{-2}$ have been reported for $H$. decipiens in the Indian River Lagoon (Kenworthy 2000) and on the West Florida Shelf, northwest of Red Bay Bank (Hammerstrom et al. unpubl. data). In both annual and perennial meadows of $Z$. marina seedling densities can be as high as $800 \mathrm{~m}^{-2}$ (Robertson \& Mann 1984, Thayer et al. 1984). For the primary colonizer, Syringodium filiforme, seedling densities as high as $20 \mathrm{~m}^{-2}$ were observed in a recently grazed $S$. filiforme meadow located within $10 \mathrm{~km}$ of Red Bay Bank (Peterson et al. 2002). However, S. filiforme seedlings reportedly did not contribute to the recovery of this overgrazed meadow, presumably due to sediment instability (Peterson et al. 2002). Seedling densities of the related Pacific climax species Thalassia hemprichii are as high as 22 to 32 seedlings $\mathrm{m}^{-2}$ (Rollon et al. 2001). The Mediterranean climax species Posidonia oceanica has seedling densities from 1 to $6 \mathrm{~m}^{-2}$ (Balestri et al. 1998). With the exception of the relatively high seedling densities reported by Rollon et al. (2001) for T. hemprichii, there is a general trend of decreasing abundance of seedlings for the longer living climax species.

Whether Thalassia testudinum recruits are important in the recovery of disturbances depends, in part, on their survival and growth. The average seedling survival in the medium and large injuries after 2 yr was $17.6 \%$. This was much lower than the $70 \%$ survival reported for 9 mo old transplanted seedlings in Biscayne Bay (Thorhaug 1974) and also for seedlings transplanted into mesocosms (Williams \& Adey 1983). In Laguna Madre, T. testudinum seedling survival after 6 mo was $22 \%$ and after 1 yr only $11 \%$ (Kaldy \& Dunton 1999). The seedlings on Red Bay Bank appear to be most vulnerable during the winter, probably due to colder water temperatures. During the winter of $2001 / 2002$, water temperatures as low as $14^{\circ} \mathrm{C}$ were recorded. This is well below $T$. testudinum's thermal limit of $19^{\circ} \mathrm{C}$, when productivity is negligible (Zieman 1974). Herbivory may also play a role in the mortality of seedlings. All of the seedlings collected showed evidence of leaf grazing. The additional mortality of the $1 \mathrm{yr}$ old seedlings following their second winter may 
have been caused by the combined effect of grazing and colder winter water temperatures. In a previous study loss of seedlings also occurred due to severe storm events (Whitfield et al. 2002).

Compared to the rhizome growth of mature plants, seedling-growth and shoot-formation rates were slow on Red Bay Bank. Horizontal rhizome extension rates of mature Thalassia testudinum range from 22 to $152 \mathrm{~cm} \mathrm{yr}^{-1}$ (Marba \& Duarte 1998), whereas the mean and maximum rhizome-elongation rates were 6.0 and $27.9 \mathrm{~cm} \mathrm{yr}^{-1}$, respectively, for $1 \mathrm{yr}$ old seedlings in the small-scale study. In the large-scale study we estimated that the average rhizome-elongation rate for 1 yr old seedlings was $6.6 \mathrm{~cm} \mathrm{yr}^{-1}$. However, if we backcalculate the rhizome-elongation rate for the oldest seedling ( $65 \mathrm{~cm}$ rhizome, $4.8 \mathrm{yr}$ ), this yields an annual rate of $13.5 \mathrm{~cm} \mathrm{yr}^{-1}$. In Laguna Madre, 1-yr-old seedlings averaged $12 \mathrm{~cm} \mathrm{yr}^{-1}$ (Kaldy \& Dunton 1999), and Biscayne Bay seedling transplants treated with growth hormones grew $7.0 \mathrm{~cm} \mathrm{yr}^{-1}$ (Thorhaug 1974). Based on these comparisons, estimated seedlinggrowth rates are similar across long distances in the Gulf of Mexico and comparable between natural and transplanted populations. Likewise, shoot-formation rates were also relatively slow. Seedlings in the largescale study produced 1.8 new short shoots in the first year, and 2.4, in Year 2, compared to 3.2 short shoots after 1 yr in Laguna Madre (Kaldy \& Dunton 1999). In contrast, mature $T$. testudinum produce between 4 and 10 short shoots $\mathrm{yr}^{-1}$ (Duarte 1991).

Inter-annual variability in reproductive effort has been reported in several studies, including the suggestion that sexual reproduction may at times be prolific (Phillips 1960, Orpurt \& Boral 1964, Grey \& Moffler 1978, Lewis \& Phillips 1980, Rollon et al. 2001). Our observations of Thalassia testudinum reproductive output on Red Bay Bank also reflect spatial and temporal variability; coupled with low seedling density and the difficulty associated with identifying seedlings within seagrass beds, this may explain why some researchers have concluded that $T$. testudinum seedlings do not make a significant contribution to seagrass bed maintenance (Patriquin 1975, Zieman 1975, Williams 1990). Even though seedling densities and growth rates are low, our observations suggest that $T$. testudinum seedling recruitment is a regular and reliable source of recovery in physically disturbed habitats on Red Bay Bank, especially since there are conditions within many of the disturbances where vegetative regrowth from the perimeter appears to be severely limited. Often the deeply excavated disturbances show very little vegetative recovery, due to the steep topographic gradient and the resulting physical instability. In several cases, the disturbances have actually increased in size, especially where they have been affected by a hurricane (Whitfield et al. 2002). Therefore, if annual recruitment is a reliable source of seedlings with sufficient survival rates over longer time periods, $T$. testudinum seedlings may eventually make a significant contribution to recovery, substituting for rhizome expansion from adjacent populations.

\section{Evidence of seedling redistribution and dispersal}

In the small-scale study, seedlings recruited into the disturbance areas, for $8 \mathrm{mo}$, beginning with the peak recruitment period in September 2000 and continuing until May 2001. During the recruitment period in late summer and early fall, seedlings were often seen floating in seagrass wrack with sediment particles adhered to their roots. This suggests that seedlings were previously rooted and subsequently uprooted, extending the time and distance over which seedlings could disperse. Kaldy \& Dunton (1999) estimated that fruits could float for as long as $10 \mathrm{~d}$ and disperse as far as $15 \mathrm{~km}$, but did not examine the dispersal of mature seedlings. Yet it seems likely that given the numerous observations of their presence in drift material and the extended period of time seedlings recruited on Red Bay Bank, long-distance dispersal is possible (Manuel F. Merello pers. obs.). This is supported by a recent molecular study that identified genotypic similarity between Thalassia testudinum populations as far apart as Panama, the Florida Keys, and Bermuda. This suggests a mechanism for long-distance dispersal of genotypes that may include either vegetative fragments or seedlings (Waycott \& Barnes 2001). Long-distance dispersal of fruits and seedlings is also hypothesized as an explanation for the presence of isolated Thalassia hemprichii beds off the Philippine Kalayaan Island Group (Rollon et al. 2001). T. hemprichii is a closely related Pacific seagrass species with a similar reproductive strategy to T. testudinum (den Hartog 1971, Kuo et al. 1991, Rollon et al. 2003). Rollon et al. (2001) hypothesized that seedlings likely play a major role in the establishment of isolated $T$. hemprichii beds due to the young age $(<1 \mathrm{yr})$, fast expansion rate, high reproductive output, and high seedling recruitment densities ( 22 to 32 seedlings $\mathrm{m}^{-2}$ ).

\section{CONCLUSION}

The degree to which Thalassia testudinum seedlings may 'jump start' the recovery process in subtropical seagrass communities is still a matter of debate. Although seedling densities were low, most of the survivers exhibited important growth characteristics, such as the development of new apical meristems. 
Therefore, these seedlings may be able to contribute to recovery after disturbances, even under such adverse conditions as unstable sediments, high currents, and variable water temperatures, although high mortality can also be expected.

Whether the recruitment densities found in the physically damaged areas in this study are representative of Thalassia testudinum seedling recruitment is an important question for future studies. To further examine $T$. testudinum seedling dynamics, future investigations should include comparisons of seedling recruitment over time in different disturbance types and hydrodynamic regimes, as well as recruitment into existing T. testudinum beds. Molecular genetics techniques may greatly improve the efficiency of seedling dynamics studies within intact seagrass beds that could otherwise only be accomplished through destructive sampling. Because T. testudinum seedlings have a long-distance dispersal strategy they are thought to primarily function in the initial establishment of seagrass beds far from the original source beds. This strategy, known as initial seedling recruitment (ISR) discounts the importance of $T$. testudinum seedlings in the maintenance of established beds (Eriksson 1989, Inglis 2000). In contrast, other seagrass species with smaller seeds and a limited dispersal capability exhibit the repeated seedling recruitment strategy (RSR) and consistently recruit into seagrass beds (Eriksson 1989, Inglis 2000). Previous research and genetics studies suggest that $T$. testudinum may exhibit both types of recruitment strategies (Kirsten et al. 1998, Davis et al. 1999, Rollon et al. 2001, Waycott \& Barnes 2001). Future studies may be able to resolve the RSR versus ISR debate for this species.

The results of this study suggest that Thalassia testudinum seedlings may be an important component to the recovery of disturbances within seagrass beds. If the results of this research are verified in future studies, the role of $T$. testudinum seedlings within the context of the seagrass community succession paradigm may need to be included as part of this important ecological process.

Acknowledgements. Funding for this research was provided by the National Oceanic and Atmospheric Administration's National Sanctuary Program and the Damage Assessment Program. We would like to thank the following people for their encouragement and much needed field assistance, K. Kirsch, S. Meehan, A. Schwarzschild, A. Uhrin, C. Bonn, M. Fonseca, and K. Willis. We also thank B. Julius for his support of this research both financially and intellectually. Thanks to M. Fonseca for his line drawing of a Thalassia testudinum seedling. We also appreciate comments and suggestions by A. Uhrin, P. Biber, and P. Marraro. We thank 3 anonymous reviewers, whose comments and suggestions greatly improved this manuscript.

\section{LITERATURE CITED}

Balestri E, Piazzi L, Cinnelli F (1998) Survival and growth of transplanted and natural seedlings of Posidonia oceanica (L.) Delile in a damaged coastal area. J Exp Mar Biol Ecol 228:209-225

Campey ML, Kendrick GA, Walker DI (2002) Interannual and small-scale variability in sexual reproduction of the seagrasses Posidonia coriacea and Heterozostera tasmanica, southwestern Australia. Aquat Bot 74:287-297

Davis JL, Childers DL, Kuhn DN (1999) Clonal variation in a Florida Bay Thalassia testudinum meadow: molecular genetic assessment of population structure. Mar Ecol Prog Ser 186:127-136

Dawes CJ, Andorfer J, Rose C, Uranowski C, Ehringer N (1997) Regrowth of the seagrass Thalassia testudinum into propeller scars. Aquat Bot 2:139-155

den Hartog C (1971) The dynamic aspect in the ecology of sea-grass communities. Thalassia Jugosl 7:101-112

Duarte CM (1991) Allometric scaling of seagrass form and productivity. Mar Ecol Prog Ser 77:289-230

Durako MJ, Moffler MD (1985) Observations on the reproductive ecology of Thalassia testudinum (Hydrocharitaceae). III. Spatial and temporal variations in repoductive patterns within a seagrass bed. Aquat Bot 22:265-276

Durako MJ, Moffler MD (1987) Factors affecting the reproductive ecology of Thalassia testudinum (Hydrocharitaceae). Aquat Bot 27:79-95

Durako MJ, Hall MO, Sargent F, Peck S (1992) Propeller scars in seagrass beds: an assessment and experimental study of recolonization in Weedon Island State Preserve, Florida. In: Webb FJ (ed) The 19th annual conference on wetlands restoration and creation. Hillsborough Community College, Plant City, FL, p 42-53

Eriksson O (1989) Seedling dynamics and life histories in clonal plants. Oikos 55:231-238

Folit R, Morris R (1992) Beds, boats and buoys: a study in protecting seagrass beds from motorboat propeller damage. Sarasota Bay National Estuarine Program, Sarasota, FL

Fourqurean JW, Powell GVN, Kenworthy WJ, Zieman JC (1995) The effects of long-term manipulation of nutrient supply on competition between the seagrasses Thalassia testudinum and Halodule wrightii in Florida Bay. Oikos 72:349-358

Fourqurean JW, Willsie A, Rose CD, Rutten LM (2001) Spatial and temporal patterns in seagrass community composition and productivity in south Florida. Mar Biol 138:341-354

Ginsburg RN, Lowenstam HA (1958) The influence of marine bottom communities on the depositional environment of sediments. J Geol 66:310-318

Grey WF, Moffler MD (1978) Flowering of the seagrass Thalassia testudinum (Hydrocharitaceae) in the Tampa Bay, Florida area. Aquat Bot 5:251-259

Hemminga MA, Duarte CM (2000) Seagrass ecology. Cambridge University Press, Cambridge, UK

Inglis GJ (2000) Variation in the recruitment behavior of seagrass seeds: implications for population dynamics and resource management. Pac Conserv Biol 5:251-259

Kaldy JE, Dunton KH (1999) Ontogenetic photosynthetic changes, dispersal and survival of Thalassia testudinum (turtle grass) seedlings in a sub-tropical lagoon. J Exp Mar Biol Ecol 240:193-212

Kenworthy WJ (2000) The role of sexual reproduction in maintaining populations of Halophila decipiens: implication for the biodiversity and conservation of tropical seagrass ecosystems. Pac Conserv Biol 5:260-268

Kenworthy WJ, Schwarzschild AC (1998) Vertical growth and 
short-shoot demography of Syringodium filiforme in outer Florida Bay, USA. Mar Ecol Prog Ser 173:25-37

Kenworthy WJ, Fonseca MS, Whitfield PE, Hammerstrom KK (2002) Analysis of seagrass recovery in experimental excavations and propeller-scar disturbances in the Florida Keys National Marine Sanctuary. J Coast Res 37:75-85

Kirsten JH, Dawes CJ, Cochrane BJ (1998) Randomly amplified polymorphism detection (RAPD) reveals high genetic diversity in Thalassia testudinum banks ex König turtlegrass. Aquat Bot 61:269-287

Kuo J, Coles RG, Lee Long WJ, Mellors JE (1991) Fruits and seeds of Thalassia hemprichii (Hydrocharitaceae) from Queensland, Australia. Aquat Bot 40:165-173

Lewis RR, Phillips RC (1980) Occurrence of seeds and seedlings of Thalassia testudinum Banks ex König in the Florida Keys (USA). Aquat Bot 9:377-380

Marba N, Duarte CM (1998) Rhizome elongation and seagrass clonal growth. Mar Ecol Prog Ser 174:269-280

Oppenheimer CH (1963) Effects of Hurricane Carla on the ecology of Redfish Bay, Texas. Bull Mar Sci Gulf Caribb 13:59-72

Orpurt PA, Boral LL (1964) The flowers, fruits, and seeds of Thalassia testudinum Koenig. Bull Mar Sci Gulf Caribb 14: 296-302

Orth RJ, Harwell MC, Bailey EM, Bartholomew A, Jawad JT, Lombana AV, Moore KA, Rhode JM, Woods HE (2000) A review of issues in seagrass seed dormancy and germination: implications for conservation and restoration. Mar Ecol Prog Ser 200:277-288

Patriquin DG (1973) Estimation of growth rate, production and age of the marine angiosperm Thalassia testudinum König. Caribb J Sci 13:111-123

Patriquin DG (1975) 'Migration' of blowouts in seagrass beds at Barbados and Carriacou, West Indies, and its ecological and geological implications. Aquat Bot 1:163-189

Peterson BJ, Rose CD, Rutten LM, Fourqurean JW (2002) Disturbance and recovery following catastrophic grazing: studies of a successional chronosequence in a seagrass bed. Oikos 97:361-370

Phillips RC (1960) Observations on the Ecology and distribution of the Florida seagrasses. Fla Board Conserv Mar Lab Prof Pap Ser 2:1-72

Robertson AI, Mann KH (1984) Disturbance by ice and lifehistory adaptations of the seagrass Zostera marina. Mar Biol 80:131-142

Rollon RN, Cayabyab NM, Fortes MD (2001) Vegetative dynamics and sexual reproduction of monospecific Thalassia hemprichii meadows in the Kalayaan Island Group. Aquat Bot 71:239-246

Rollon RN, Vermaat JE, Nacorda HME (2003) Sexual reproduction in SE Asian seagrasses: the absence of a seed bank in Thalassia hemprichii. Aquat Bot 75:181-185

Rose CD, Sharp WC, Kenworthy WJ, Hunt JH and 6 others (1999) Overgrazing of a large seagrass bed by the sea urchin Lytechinus variegatus in outer Florida Bay. Mar Ecol Prog Ser 190:211-222

Sargent FJ, Leary TJ, Crewz DW, Kruer CR (1995) Scarring of Florida's seagrasses: assessment and management. Fla Mar Res Inst Tech Rep 1h/94:1-37

Editorial responsibility: Otto Kinne (Editor), Oldendorf/Luhe
Thayer GW, Kenworthy WJ, Fonseca MS (1984) The ecology of eelgrass meadows of the Atlantic coast: a community profile. FWS/OBS-84/02, US Fish and Wildlife Service, Washington, DC

Thomas LP, Moore DR, Work RC (1961) Effects of Hurricane Donna on the turtle grass beds of Biscayne Bay, Florida. Bull Mar Sci Gulf Caribb 11:191-197

Thorhaug A (1974) Transplantation of the seagrass Thalassia testudinum König. Aquaculture 4:177-183

Tilmant JT, Curry RW, Jone R, Szmant A and 6 others (1994) Hurricane Andrew's effects on marine resources. Bioscience 44:230-237

Tomlinson PB (1969) On the morphology and anatomy of turtle grass, Thalassia testudinum (Hydrocharitaceae). III. Floral morphology and anatomy. Bull Mar Sci 19:286-305

Tomlinson PB (1974) Vegetative morphology and meristem dependence - the foundation of productivity in seagrasses. Aquaculture 4:107-130

Tomlinson PB, Vargo GA (1966) On the morphology and anatomy of turtle grass, Thalassia testudinum (Hydrocharitaceae). I. Vegetative morphology. Bull Mar Sci 16:748-761

Waycott M, Barnes PAG (2001) AFLP diversity within and between populations of Caribbean seagrass Thalassia testudinum (Hydrocharitaceae). Mar Biol 139:1021-1028

Whitfield PE, Kenworthy WJ, Hammerstrom KK, Fonseca MS (2002) The role of storms in the expansion of disturbances initiated by motor vessels on subtropical seagrass-coral banks. J Coast Res 37:86-99

Williams SL (1987) Competition between seagrasses Thalassia testudinum and Syrindodium filiforme in a Caribbean lagoon. Mar Ecol Prog Ser 35:91-98

Williams SL (1990) Experimental studies of Caribbean seagrass bed development. Ecol Monogr 60:449-469

Williams SL, Adey WH (1983) Thalassia testudinum Banks ex König seedling success in a coral reef microcosm. Aquat Bot 16:181-188

Zar JH (1984) Biostatistical analysis. Prentice-Hall, Englewood Cliffs, NJ

Zieman JC (1972) Origin of circular beds of Thalassia (Spermatophyta: Hydrocharitaceae) in South Biscayne Bay Florida and their relationship to mangrove hammocks. Bull Mar Sci 22:559-574

Zieman JC (1974) Quantitative and dynamic aspects of the ecology of turtle grass, Thalassia testudinum. In: Cronin LE (ed) Estuarine research, Vol I. Chemistry, biology, and the estuarine system. Academic Press, New York, p 541-562

Zieman JC (1975) Seasonal variation of turtle grass, Thalassia testudinum König, with reference to temperature and salinity effects. Aquat Bot 1:107-123

Zieman JC (1976) The ecological effects of physical damage from motor boats on turtle grass beds in southern Florida. Aquat Bot 2:127-139

Zieman JC (1982) The ecology of the seagrasses of South Florida: a community profile. FWS/OBS-82/25, US Fish and Wildlife Service, Washington, DC

Zieman JC, Zieman RT (1989) The ecology of seagrass meadows of the West Coast of Florida: a community profile. Biological report 85(7.25), US Fish and Wildlife Service, Washington, DC

Submitted: May 5, 2003; Accepted: November 11, 2003

Proofs received from author(s): February 2, 2004 